\title{
PENGARUH LITERASI KEUANGAN, PENDAPATAN SERTA MASA BEKERJA TERHADAP PERILAKU KEPUTUSAN INVESTASI
}

\author{
IGA Mertha Dewi ${ }^{1}$ \\ Ida Bagus Anom Purbawangsa ${ }^{2}$
}

\author{
${ }^{1,2}$ Fakultas Ekonomi dan Bisnis Universitas Udayana, Bali, Indonesia \\ e-mail: ghosteayu@gmail.com
}

\begin{abstract}
ABSTRAK
Responden penelitian adalah karyawan PT Bank Pembangunan Daerah Bali Cabang Renon dengan sampel sebanyak 76 orang. Teknik pengambilan sampel dalam penelitian ini menggunakan random sampling. Data dianalisis dengan menggunakan teknik PLS (Partial Least Squares). Hasil penelitian ini menunjukkan bahwa literasi keuangan, pendapatan berpengaruh positif terhadap perilaku keputusan investasi,namun masa kerja secara positif tidak berpengaruh terhadap perilaku keputusan investasi. Hal ini dikarenakan pada industri perbankan semua karyawan baik yang baru memasuki dunia kerja ataupun yang sudah lama bekerja sama-sama mendapatkan pelatihan-pelatihan serta memperoleh informasi-informasi mengenai perkembangan keuangan serta kondisi keuangan yang terjadi pada saat ini. Dengan kata lain pemahaman akan literasi keuangan serta perilaku karyawan hampir sama. Berdasarkan hasil data statistik variabel literasi keuangan memiliki pengaruh paling besar dalam menentukan perilaku keputusan investasi dibandingkan pendapatan. Hal ini menjelaskan bahwa pemahaman yang baik mengenai keuangan menjadi faktor utama dalam menentukan keputusan sebuah investasi.
\end{abstract}

Kata Kunci: literasi keuangan, pendapatan, masa bekerja dan keputusan investasi.

\begin{abstract}
Research respondents are employees of PT Bank Pembangunan Daerah Bali Branch Renon with a sample of 76 people. Sampling technique in this research use random sampling. Data were analyzed by using Multiple Linear Regression Analysis. The result of this indicate that financial literacy, income has a positive effect on investment decision behavior, but the work period positively has no effect on investment decision behavior. This is because in the banking industry, the entire new employee and who have been working long time get the training and obtain informations about financial developments and financial conditions that occur at this time. In the other words the undertanding of financial literacy and employee behavior is almost the same. Based on the results of statistical data, financial literacy variables have the most influence in determining the behavior of investment decisions compared to income. This explains that a good understanding of finance is a major factor in determining an invesment decisions.
\end{abstract}

Keywords: financial literacy, income, working period and investment decision. 


\section{PENDAHULUAN}

Pengetahuan keuangan dasar serta skill untuk mengelola sumber daya keuangan secara efektif demi kesejahteraan hidupnya diperlukan setiap individu. Kebutuhan individu dan produk finansial yang semakin kompleks menuntut masyarakat untuk memiliki financial literacy yang memadai. Memiliki penguasaan ilmu serta skill di bidang keuangan mendorong individu untuk memahami dan terlibat isu - isu nasional dibidang keuangan seperti biaya perawatan kesehatan, pajak, investasi dan memiliki akses ke dalam sistem keuangan. Kurangnya literasi keuangan dapat mengakibatkan rendahnya akses ke lembaga keuangan dan menghambat kemakmuran, sebab menurut calon anggota Komisioner Otoritas Jasa Keuangan, Soetiono, akses yang luas ke sistem keuangan atau sistem keuangan yang mencakup usaha mikro, masyarakat miskin dan kaum wanita, serta rumah tangga produktif, maka bisa menurunkan perbedaan pendapatan diantara masyarakat (Kompas, 13 Juni 2012).

Pengambilan keputusan investasi telah diakui sebagai salah satu faktor penting yang mempengaruhi kemampuan keuangan dan kesejahteraan secara finansial sehingga identifikasi terhadap faktor faktor yang terkait dengan keputusan investasi yang relevan merupakan salah satu isu penting bagi individu secara personal dan pembangunan secara nasional. Perubahan lingkungan investasi yang berlangsung sangat dinamis saat ini menyebabkan fokus yang tidak hanya tertuju kepada pengambilan keputusan investasi tetapi juga pada tingkat financial literacy 
serta mengenai bagaimana dampak tingkat financial literacy tersebut terhadap pengambilan keputusan investasi (Janor et al, 2016).

Survei World Bank tahun 2010 serta sensus yang dilaksanakan Badan Pusat Statistik (BPS) ditemukan fenomena bahwa separuh penduduk Indonesia tidak memiliki akses atas layanan lembaga keuangan formal. Hal ini mengindikasikan bahwa sistem keuangan belum berjalan secara optimal serta masih adanya ruang untuk perbaikan dalam rangka peningkatan akses masyarakat kepada layanan lembaga keuangan. Dalam rangka pelaksanaan program Keuangan Inklusif sejak tahun 2013, Bank Indonesia (BI) bersama pemerintah menyusun Strategi Nasional Keuangan Inklusif (SNKI) yang salah satu pilar utamanya adalah Edukasi Keuangan yang bertujuan untuk meningkatkan tingkat melek keuangan masyarakat Indonesia financial literacy.

Akibat dari kurangnya financial literacy di Indonesia menyebabkan masyarakat mengalami kerugian, baik akibat penurunan kondisi perekonomian dan inflasi atau karena berkembangnya sistem ekonomi yang cenderung boros karena masyarakat semakin konsumtif. Masyarakat banyak memanfaatkan kredit rumah dan kartu kredit, tetapi karena pengetahuan minim, tidak sedikit yang mengalami kerugian atau sering terjadi perbedaan perhitungan antara konsumen dan bank. Banyak masyarakat yang tidak berinvestasi atau pun tidak bisa mengakses pasar modal dan pasar uang karena memang tidak memiliki pengetahuan yang cukup mengenai hal tersebut. Sementara itu edukasi finansial (financial education) masih merupakan tantangan besar di Indonesia. Edukasi finansial merupakan proses panjang yang memacu individu untuk memiliki 
rencana keuangan dimasa depan demi mendapatkan kesejahteraan sesuai dengan pola dan gaya hidup yang dijalani (Bank Indonesia, 2014).

Beberapa penelitian sebelumnya (Xiao,el,al, 2008: Mandell dan Klein, 2009) menyimpulkan bahwa cara terbaik unuk memperbaiki perilaku di usia dewasa adalah dengan cara mengajarkan perilaku yang baik sejak kecil, termasuk perilaku keuangan (financial behavior). Sementara di Indonesia sendiri pendidikan keuangan pribadi (personal finance) masih jarang ditemui baik itu disekolah dasar sampai dengan perguruan tinggi.

Study di Autralia yang dilakukan pada tahun 2004 oleh Commonwealth Foundation bekerja sama dengan universitas dan lembaga penelitian mempunyai tujuan untuk menyelidiki kemampuan orang untuk membuat keputusan investasi dan menganalisis hubungannya dengan financial literacy dan dampaknya terhadap individu. Penelitian ini menampilkan profil orang Australia tersebut dengan tingkat financial literacy terendah dan menunjukkan manfaat potensial yang signifikan bagi individu dan ekonomi yang mempunyai financial literacy yang lebih baik. Hasilnya menunjukkan bahwa faktor sosioekonomi seperti pendapatan terkait dengan keputusan investasi dan individu yang lebih terpelajar memiliki pendapatan lebih tinggi secara signifikan lebih cenderung memiliki bisnis dan kemampuan lebih untuk meningkatkan 10 persen dari pendapatan tahunan mereka dalam seminggu, meningkatkan kemampuan mereka untuk bertahan dari tekanan keuangan tiba-tiba. 
Kesulitan keuangan bukan hanya disebabkan oleh rendahnya tingkat penghasilan, tetapi juga disebabkan kesalahan dalam manajemen keuangan, untuk itu, dibutuhkan literasi keuangan yang memadai. Literasi keuangan dalam bentuk semua aspek keuangan pribadi bukan ditunjukan untuk mempersulit atau mengekang orang dalam menikmati hidup serta menggunakan uang yang mereka miliki, tetapi justru dengan literasi keuangan, individu atau keluarga dapat menikmati hidup dengan menggunakan sumber daya keuangannya dengan tepat dalam rangka mencapai tujuan keuangan pribadinya. (Warsono, 2010).

Banyak hal yang mengakibatkan masyarakat semakin konsumtif dan melakukan pembelian yang impulsif tanpa pertimbangan kedepan, seperti semakin maraknya belanja online, pusat perbelanjaan dimana-mana, kemudahan proses dalam memiliki kartu kredit, gaya hidup, persaingan antar karyawan, serta tingkat pendidikan. Tanpa memiliki pengetahuan dan skill di bidang keuangan, kemungkinan melakukan kesalahan dalam pengelolaan sumber daya keuangan akan semakin besar dan kesejahteraan pun akan sulit dicapai.

Kondisi tersebut sangat kompleks karena sebagian besar karyawan menghadapi masalah seperti melakukan pembayaran kewajiban yang didebet setiap bulan, keperluan rumah tangga, keperluan yang sifatnya tak terduga ataupun disebabkan pengelolaan keuangan pribadi yang salah (tidak adanya penganggaran), serta gaya hidup terbiasa dengan pola konsumtif sehingga menjadi sangat boros ditambah dengan kurangnya pengetahuan mengenai keuangan itu sendiri (Nababan, 2012). 
Memiliki literasi keuangan merupakan hal vital untuk mendapatan kehidupan yang sejahtera. Dengan pengelolaan keuangan yang tepat yang tentunya ditunjang oleh literasi keuangan yang baik, maka taraf kehidupannya diharapkan dapat meningkat, hal ini berlaku untuk setiap penghasilan, karena bagaimanapun tingginya tingkat penghasilan seseorang, tanpa pengelolaan yang tepat, finansial akan sulit dicapai (Awais et al, 2016). Pengetahun keuangan untuk setiap karyawan khususnya yang biasa berkaitan langsung dengan bidang keuangan selayaknya mempunyai kemampuan untuk mengelola keuangannya untuk menghasilkan keputusan investasi yang lebih baik contohnya seorang karyawan yang bekerja di bidang bisnis perbankan.

Salah satu bisnis perbankan yang berpusat dan berkembang dengan pesat di wilayah Propinsi Bali adalah PT Bank Pembangunan Daerah Bali. Pada bank tersebut setiap karyawan tentunya mempunyai kesempatan untuk memperoleh pinjaman dana terlebih mendapatkan kredit fasilitas sebagai karyawan. Kredit fasilitas yang dimaksudkan disini adalah kredit karyawan dengan suku bunga yang sangat ringan, berbeda dengan suku bunga yang diberikan kepada masyarakat pada umumnya.

Dalam kesempatan inilah para karyawan berbondong - bondong melakukan peminjaman dana dalam jumlah maksimum sesuai dengan ketentuan yang ada, dapat dikatakan hampir seluruh karyawan yang memenuhi ketentuan melakukan peminjaman dana melalui kredit fasilitas yang diberikan. Tentu saja hal tersebut merupakan salah satu hal yang 
mempengaruhi kondisi keuangan dari karyawan, dimana dalam hal ini apabila dana yang diperoleh tidak dikelola dengan baik dan dengan perhitungan yang matang maka tak jarang dana yang telah dipijam tadi tidak memberikan pendapatan ataupun hasil lebih dari biaya yang telah dikeluarkan.

Beberapa penelitian terdahulu mengenai literasi keuangan dilakukan oleh Atkinson dan Messy (2012) yang mengamati bahwa melek finansial cenderung lebih tinggi di antara orang dewasa di tengah-tengah siklus hidup mereka, dan biasanya lebih rendah di antara individu muda dan tua. Hasil yang dilaporkan oleh Research (2003) menunjukkan bahwa status single secara signifikan lebih mungkin untuk memiliki melek finansial rendah daripada orang yang menikah. Monticone (2010) dan Atkinson dan Messy (2012) menemukan bahwa tingkat pendapatan rendah berhubungan dengan tingkat melek finansial yang rendah. Dan, akhirnya, Chen dan Volpe (1998) dan Penelitian (2003) mengamati bahwa individu dengan pengalaman kerja lebih lama lebih melek finansial.

Studi tentang keuangan pribadi telah menguji dampak signifikan literasi keuangan, terhadap pembangunan ekonomi seperti ketidaktahuan finansial terhadap pengambilan keputusan keuangan. Di Malaysia, Faoziah et al (2013) memberikan bukti tentang efek Financial Literacy pada kesulitan keuangan di kalangan pemuda Malaysia. Studi mereka menunjukkan bahwa tingkat kesulitan keuangan responden dan financial literacy moderat dengan arah positif namun lemah. Hasilnya menunjukkan 
fakta bahwa instansi terkait dan organisasi harus berinvestasi dalam sumber daya manusia berkenaan dengan pengelolaan keuangan pribadi seperti itu pengetahuan investasi akan membantu meningkatkan tingkat melek finansial antar individu dan mencapai tujuan. Negara untuk menghasilkan produktivitas tinggi. Studi untuk negara lainnya, seperti India dan Indonesia ditunjukkan oleh Cole et al (2008) yang meneliti tingkat financial literacy sebagai faktor penentu dan pengaruhnya atas permintaan jasa keuangan. Mereka mengamati hubungan yang kuat antara financial literacy dan perilaku keuangan menemukan bahwa financial literacy memiliki korelasi penting dari perilaku keuangan rumah tangga dan kesejahteraan rumah tangga.

Studi selanjutnya yang telah menguji dampak financial literacy pada berbagai jenis keputusan investasi seperti yang dilakukan oleh Almenberg dan Soderbergh (2011) yang melihat hubungan antara financial literacy dan perencanaan pensiun orang dewasa Swedia. Tingkat financial literacy ditemukan lebih rendah di antara orang tua, wanita dan mereka yang memiliki pendidikan rendah atau pendapatan. Klapper dan Panos (2011) melakukan penelitian di Rusia menemukan bahwa pengetahuan yang lebih tinggi berhubungan positif dengan perencanaan pensiun dan perencanaan dana pensiun swasta.

Lusardi \& Mitchell (2011) melakukan penelitian di Amerika Serikat yang meneliti pengaruh financial literacy pada masa pensiun mengenai perencanaan sampai sejauh mana mereka dapat membuat keputusan 
pensiun dan cukup memiliki pengetahuan tentang ekonomi dan keuangan untuk merencanakan masa pensiun. Temuan ini menyoroti masalah dengan pengetahuan keuangan di mana banyak responden tidak memiliki pengetahuan kunci tentang konsep keuangan kritis termasuk inflasi, dan risiko bunga diversifikasi dan gagal merencanakan pensiun.

Yoong et al (2012) melakukan penelitian di Malaysia menunjukkan hubungan yang signifikan antara pembelajaran finansial dan penilaian perilaku keuangan pribadi. Studi ini juga mendeteksi dampak perbedaan usia di mana kelompok usia yang lebih tua lebih dari 50 tahun) mempengaruhi hubungan antara pembelajaran finansial dan persepsi subjektif kepuasan dengan keuangan pribadi. Welly et al (2016) melakukan penelitian pada dosen, karyawan, dan mahasiswa aktif jurusan manajemen dan akuntansi di STIE Multi Data Palembang menemukan bahwa literasi keuangan (pemahaman keuangan) tidak mempengaruhi keputusan investasi.

Berdasarkan paparan yang telah diuraikan, maka terdapat perumusan masalah sebagai berikut: 1) Apakah Literasi Keuangan berpengaruh signifikan terhadap perilaku keputusan investasi pada karyawan PT Bank Pembangunan Daerah Bali Cabang Renon? 2) Apakah pendapatan berpengaruh signifikan terhadap perilaku keputusan investasi pada karyawan PT Bank Pembangunan Daerah Bali Cabang Renon? 3) Apakah masa bekerja berpengaruh signifikan terhadap perilaku keputusan 
investasi pada karyawan PT Bank Pembangunan Daerah Bali Cabang Renon?

Investasi merupakan pengorbanan yang dilakukan pada saat sekarang dengan tujuan untuk mendapatkan manfaat yang lebih besar di masa yang akan datang (Haming dan Basalamah, 2010). Pengambilan keputusan investasi adalah proses untuk menyimpulkan serta membuat keputusan dari beberapa permasalah, membuat pilihan diantara dua atau lebih alternatif investasi atau bagian dari transformasi input menjadi output.

Dalam pengambilan keputusan investasi, seorang investor banyak dipengaruhi oleh perilaku. Perilaku disini merupakan perilaku keuangan dalam hal mengelola keuangan yang disebut dengan financial litreacy yang terlibat di dalamnya. Financial literacy sebagai pengetahuan keuangan individu juga merupakan kebutuhan dasar bagi setiap orang agar terhindar dari permasalahan keuangan. Kesulitan keuangan muncul bukan hanya dilihat dari fungsi pendapatan saja, namun kesalahan dalam pengelolaan keuangan (miss-management) seperti kesalahan penggunaan kredit dan tidak adanya perencanaan keuangan. Hal-hal tersebut terjadi karena kurangnya literasi keuangan serta pengalaman dalam diri individu tersebut.

(Welly, 2016) menyatakan bahwa literasi keuangan merupakan kemampuan seseorang dalam membuat keputusan yang efektif berhubungan dengan keuangan. Literasi keuangan membantu individu terhindar dari masalah keuangan terutama yang terjadi akibat kesalahan 
pengelolaan keuangan. Literasi keuangan bagi individu bukan sekedar sebagai ilmu pengetahuan ataupun teori saja, tetapi diharapkan dapat membuat individu lebih bijaksana dan pandai dalam mengelola aset yang dimilikinya sehingga dapat memberikan timbal - balik yang bermanfaat dalam menyokong keuangan individu baik dalam jangka pendek maupun jangka panjang. (Hisashi dan Ratna, 2016) melakukan pengujian pada nasabah salah satu asuransi yang berada di Palembang menemukan bahwa, pengetahuan umum keuangan pribadi berpengaruh terhadap keputusan investasi seseorang. Sejalan dengan Hisashi dan Ratna (Sandy, 2016) melakukan pengujian pada masyarakat Malang Raya menemukan bahwa pengetahuan umum keuangan pribadi berpengaruh terhadap keputusan investasi.

Kemudian Robb dan Woodyard (2011) secara teoritis literasi keuangan adalah bagian dari pengetahuan keuangan mengenai bagaimana pasar keuangan beroperasi harus menghasilkan individu yang membuat keputusan lebih efektif. Jagongo dan Mustwenje, (2014) menemukan bahwa sebagian besar responden tidak memahami konsep keuangan dasar, terutama yang berkaitan dengan saham, obligasi, reksadana dan konsep keuangan majemuk. Sehingga orang sering gagal dalam menyimpulkan serta mengambil keputusan. Namun berbeda dengan (Welly, 2016) menemukan bahwa pengetahuan umum keuangan pribadi tidak berpengaruh secara parsial terhadap keputusan investasi.

Berdasarkan uraian tersebut, maka dapat dirumuskan hipotesis 
sebagai berikut: H1: Literasi keuangan berpengaruh positif signifikan terhadap perilaku keputusan investasi.

John et al, (2009) terdapat hubungan yang positif antara pendapatan (income) dengan perilaku manajemen keuangan yang bertanggungjawab. Artinya semakin tinggi pendapatan maka semakin baik dan bertanggungjawab perilaku keuangannya. Hasil penelitian ini didukung oleh teori perpsektif perilaku keuangan dalam pengambil keputusan keuangan yang adaptif berarti bahwa sifat keputusan dan lingkungan di mana itu membuat pengaruh jenis proses yang digunakan. Semakin baik keadaan sosiodemografi seseorang akan berpengaruh terhadap jenis proses pengambilan keputusan investasi yang digunakan kearah yang baik. V. Sudheer (2015) menemukan hasil bahwa pendapatan berpengaruh signifikan terhadap kebutuhan serta keputusan investasi.

Berdasarkan uraian tersebut, maka dapat dirumuskan hipotesis sebagai berikut: H2: Pendapatan berpengaruh positif signifikan terhadap perilaku keputusan investasi.

Research (2008) mengatakan bahwa seseorang yang tidak bekerja, memiliki tingkat financial literacy lebih rendah karena tidak pernah terlibat dengan isu - isu mengenai finansial. Hal senada juga diutarakan oleh Calamato (2010), bahwa kondisi kerja dapat mempengaruhi kinerja seseorang, sehingga dapat meningkatkan pendapatan dan mengelola gajinya dengan baik untuk kepentingannya, begitu juga dengan Krishna, Rofaida \& Sari (2010) yang 
menemukan bahwa masa bekerja seseorang berpengaruh secara positif dan signifikan terhadap perilaku keuangan.

Berdasarkan uraian tersebut, maka dapat dirumuskan hipotesis sebagai berikut: H3: Masa Bekerja berpengaruh positif signifikan terhadap perilaku keputusan investasi.

\section{METODE PENELITIAN}

Variabel yang diidentifikasi dalam penelitian ini adalah sebagai berikut: 1) Variabel bebas (eksogen). Variabel bebas dalam penelitian ini adalah literasi keuangan (X1), pendapatan (X2), masa bekerja (X3). 2) Variabel terikat (endogen). Variabel terikat dalam penelitian adalah perilaku keputusan investasi (Y).

Populasi dalam penelitian ini adalah seluruh karyawan yang berstatus aktif bekerja sampai bulan Maret 2017 PT Bank Pembangunan Daerah Bali Cabang Renon sebanyak 95 orang. Teknik pengambilan sampel menggunakan random sampling, semua responden memiliki kesempatan yang sama tergantung dari siapa yang ditemui pada saat penelitian dilakukan. Dengan perhitungan sampel, menggunakan perhitungan sampel slovin, dengan rumus sebagai berikut :

Dimana :

$$
\mathrm{n}=\frac{N}{1+N(e) 2}
$$

$\mathrm{n}=$ Jumlah Sampel

$\mathrm{N}=$ Jumlah Populasi

$\mathrm{e}=$ Tingkat kesalahan $(5 \%)$

$$
\mathrm{n}=\frac{95}{1+95(0,05)^{2}}
$$




$$
\mathrm{n}=76
$$

Sehingga dari hasil perhitungan menggunakan rumus diatas, didapatkan jumlah sampel dari populasi yang akan diteliti sebanyak 76 responden.

Dalam memperoleh data yang sesuai dengan tujuan penelitian, maka dibutuhkan alat pengumpulan data yang disebut instrument penelitian. Instrument penelitian adalah suatu alat yang digunakan mengukur fenomena alam maupun sosial yang diamati, secara spesifik semua fenomena ini disebut variabel penelitian (Sugiyono, 2013).

Penelitian ini menggunakan teknik pengumpulan data survei dengan menggunakan kuesioner. Analisis deskriptif digunakan untuk mengetahui karakteristik responden dan deskripsi responden terhadap indikator indikator dalam bentuk atau merefleksikan variabel. Analisis deskriptif juga ditujukan untuk menggambarkan kecendrungan tanggapan responden terhadap item-item pertanyaan yang berkaitan dengan variabel penelitian.

Analisis inferensial digunakan untuk menguji hipotesis yang diformulasikan dalam penelitian. Data penelitian ini dianalisis dengan menggunakan pendekatan Partial Least Square (PLS) dengan proses perhitungan dibantu program aplikasi software Smart PLS, sehingga menghasilkan suatu model yang layak (fit) (Narindra, 2017).

\section{HASIL PENELITIAN}

Karakeristik responden dalam penelitian digambarkan dengan menyajikan karakteristiknya berdasarkan tingkat pendapatan serta masa bekerja. Secara rinci karakteristik responden disajikan pada Tabel 1. 
Tabel 1.

Karakteristik Responden

\begin{tabular}{|c|c|c|c|c|}
\hline No. & Variabel & Klasifikasi & Jumlah(Orang) & Persentase \\
\hline \multirow{5}{*}{1} & \multirow{5}{*}{$\begin{array}{c}\text { Tingkat } \\
\text { Pendapatan }\end{array}$} & $3.500 .000-5.900 .000$ & 14 & 18.4 \\
\hline & & $6.000 .000-9.900 .000$ & 9 & 11.8 \\
\hline & & $10.000 .000-13.900 .000$ & 15 & 19.7 \\
\hline & & $14.000 .000-19.900 .000$ & 28 & 36.9 \\
\hline & & $>20.000 .000$ & 10 & 13.2 \\
\hline \multirow{7}{*}{2} & \multirow{6}{*}{$\begin{array}{c}\text { Masa } \\
\text { Bekerja }\end{array}$} & Jumlah & 76 & 100 \\
\hline & & $<1$ tahun & 0 & 0 \\
\hline & & $1 \mathrm{sd} 2$ tahun & 1 & 1.3 \\
\hline & & 3 sd 5 tahun & 26 & 34.2 \\
\hline & & 6 sd 10 tahun & 16 & 21 \\
\hline & & $>10$ tahun & 33 & 43.5 \\
\hline & & Jumlah & 76 & 100 \\
\hline
\end{tabular}

Sumber: Data yang diolah, 2017

Berdasarkan klasifikasi tingkat pendapatan, hasil penelitian menunjukkan bahwa responden dengan tingkat pendapatan 3.500.000 - 5.900.000 sebesar 18.4 persen, pendapatan $6.000 .000-9.900 .000$ sebesar 11.8 persen, pendapatan 10.000.000 - 13.900.000 sebesar 19.7 persen, pendapatan 14.000 .000 19.900.000 sebesar 36.9 persen, pendapatan > 20.000.000 sebesar 13.2 persen. Berdasarkan klasifikasi masa kerja, hasil penelitian menunjukkan bahwa responden dengan masa bekerja $<1$ tahun sebesar 0 persen, masa bekerja 1 sd 2 tahun sebesar 1.3 persen, masa bekerja 3 sd 5 tahun sebesar 34.2 persen, masa bekerja 6 sd 10 tahun 21 persen, masa bekerja >10 tahun sebesar 43.5 persen.

Uji validitas digunakan untuk mengetahui valid atau tidaknya kuesioner dalam pengumpulan data. Berikut hasil uji validitas disajikan dalam Tabel 2. 
Tabel 2.

\section{Hasil Uji Validitas}

\begin{tabular}{l} 
Variabel \\
\hline Literasi Keuangan \\
Kecakapan dalam mengelola keuangan pribadi dapat membantu kita terhindar
\end{tabular}
dari menjadi korban penipuan keuangan, dimana pada saat ini banyak aksi penipuan keuangan.

Simbol T hitung

Salah satu manfaat penganggaran keuangan pribadi yaitu dapat digunakan sebagai alat penelitian kelebihan dan kekurangan dana

$\mathrm{X} 1.2 \quad 0,879$

Kelayakan kredit anda akan meningkat jika anda dapat menunjukkan catatan/bukti bahwa anda tidak pernah gagal bayar

$\mathrm{X} 1.3 \quad 0,828$

Jika tingkat suku bunga naik maka harga obligasi akan turun

$\mathrm{X} 1.4 \quad 0,553$

Tujuan utama memiliki asuransi adalah melindungi diri dari kemungkinan kerugian yang dialami

$\mathrm{X} 1.5 \quad 0,788$

\section{Perilaku Keputusan Investasi}

Saya dapat memperhitungkan keamanan dan risiko dalam berinvestasi (keamanan dalam suatu investasi berarti risiko kerugian minimal)

Y1.1 0,743

Saya dapat memprediksi komponen faktor risiko yaitu yang berkaitan dengan investasi khusus berubah dari waktu ke waktu

Y1.2 0,907

Saya dapat menganalisa return (tingkat pengembalian modal) dari investasi yang dilakukan

Y1.3 $\quad 0,851$

Saya dapat memahami pertumbuhan investasi yaitu mengenai nilai uang pada masa mendatang

Y1.4 0,919

Saya dapat menganalisa tingkat likuiditas (tingkat pengembalian modal) dari investasi yang saya lakukan

Sumber: Data diolah, 2017

Pada Tabel 2., seluruh item pertanyaan menunjukkan nilai $r_{\text {hitung }}>$

$\mathrm{r}_{\text {tabel }}(0,361)$ pada nilai signifikansi 5 persen. Hal ini dapat dikatakan 
bahwa seluruh indikator konstruk dalam penelitian ini adalah valid sehingga dapat digunakan sebagai instrumen penelitian.

Uji reliabilitas intrumen penelitian dilakukan dengan menggunakan rumus cronbach alpha dimana taraf untuk $\alpha=0,05$. Instrumen penelitian dapat dikatakan reliabel jika nilai alpha lebih besar dari 0,60. Ringkasan hasil uji reliabilitas instrumen penelitian yang digunakan disajikan pada Tabel 2. sebagai berikut:

\section{Tabel 3.} Hasil Uji Reliabilitas

\begin{tabular}{lcc}
\hline \multicolumn{1}{c}{ Variabel } & Simbol & Cronbach Alpha \\
\hline Literasi Keuangan & X1 & 0,851 \\
Perilaku Keputusan Investasi & Y & 0,901 \\
\hline Sumber: Data diolah, 2017 & &
\end{tabular}

Berdasarkan Tabel 3. dapat diketahui bahwa seluruh indikator konstruk menunjukkan nilai cronbach alpha >0,60. Dengan demikian, dapat dikatakan bahwa seluruh indikator konstruk dalam penelitian ini reliabel dan layak untuk digunakan sebagai instrumen penelitian.

Model mempunyai discriminant validity yang cukup jika akar kuadrat AVE untuk setiap variabel lebih besar daripada korelasi antara konstruk dan konstruk lainnya dalam model. 
Tabel 4.

Hasil Discriminant Validity

Korelasi

\begin{tabular}{lcccccc}
$\begin{array}{c}\text { Variabel } \\
\text { Penelitian }\end{array}$ & AVE & $\begin{array}{c}\text { Akar } \\
\text { AVE }\end{array}$ & $\begin{array}{c}\text { Literasi } \\
\text { Keuangan } \\
\text { (X1) }\end{array}$ & $\begin{array}{c}\text { Pendapatan } \\
(\mathbf{X 2})\end{array}$ & $\begin{array}{c}\text { Masa } \\
\text { Bekerja } \\
\text { (X3) }\end{array}$ & $\begin{array}{c}\text { Perilaku } \\
\text { Keputusan } \\
\text { Investasi } \\
\text { (Y) }\end{array}$ \\
\hline $\begin{array}{l}\text { Literasi } \\
\text { Keuangan (X1) }\end{array}$ & 0,638 & $\mathbf{0 , 7 9 8}$ & 1,000 & & & \\
$\begin{array}{l}\text { Pendapatan (X2) } \\
\text { Masa Kerja (X3) }\end{array}$ & 1,000 & $\mathbf{1 , 0 0 0}$ & 0,582 & 1,000 & & \\
& 1,000 & $\mathbf{1 , 0 0 0}$ & 0,461 & 0,841 & 1,000 & \\
$\begin{array}{l}\text { Perilaku } \\
\text { Keputusan } \\
\text { Investasi (Y) }\end{array}$ & 0,763 & $\mathbf{0 , 8 7 3}$ & 0,800 & 0,674 & 0,551 & 1,000 \\
\hline & & & & & & \\
\hline Sumber: Data diolah, 2017 & & & & & \\
\hline
\end{tabular}

Berdasarkan Tabel 4. dapat dilihat bahwa nilai akar AVE konstruk literasi keuangan (X1) yaitu 0,798 lebih besar dari korelasi antar variabel laten dengan konstruk lainnya. Nilai akar AVE variabel Pendapatan (X2) yaitu 1,000 lebih besar dari korelasi antar variabel laten dengan konstruk lainnya. Nilai akar AVE variabel masa bekerja (X3) yaitu 1,000 lebih besar dari korelasi antar variabel laten dengan konstruk lainnya. Nilai akar AVE variabel perilaku keputusan investasi (Y) yaitu 0,873 lebih besar dari korelasi antar variabel laten dengan konstruk lainnya.

Pengujian discriminant validity lainnya adalah cara dengan menilai validitas dari variabel dari nilai AVE. Model dikatakan baik jika AVE masing-masing variabel nilainya lebih besar dari 0,50. Hasil output menunjukkan bahwa nilai AVE seluruh variabel lebih besar dari 0,50 sehingga model dapat dikatakan baik. 
Penelitian ini menggunakan pendekatan analisis Partial Least Square (PLS) untuk melakukan uji dan analisis terhadap hipotesis penelitian yang telah dikemukakan sebelumnya. Hasil analisis model empiris penelitian dengan menggunakan alat analisis Partial Least Square (PLS).

\section{Tabel 5.}

Path Cofficients

\begin{tabular}{|c|c|c|c|c|}
\hline Konstruk & $\begin{array}{c}\text { Koefisien } \\
\text { Korelasi }\end{array}$ & $t$ statistic & $p$ values & Keterangan \\
\hline 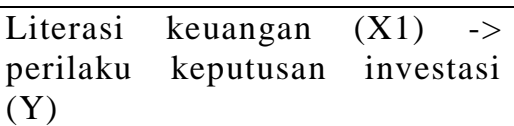 & 0,617 & 6,091 & 0,000 & Signifikan \\
\hline $\begin{array}{l}\text { Pendapatan (X2) } \rightarrow \text { perilaku } \\
\text { keputusan investasi (Y) }\end{array}$ & 0,310 & 2,062 & 0,040 & Signifikan \\
\hline $\begin{array}{l}\text { Masa bekerja (X3) } \rightarrow \text { perilaku } \\
\text { keputusan investasi (Y) }\end{array}$ & 0,006 & 0,062 & 0,950 & $\begin{array}{l}\text { Tidak } \\
\text { signifikan }\end{array}$ \\
\hline
\end{tabular}

Hasil estimasi model struktural seperti yang disajikan pada Tabel 5. menunjukkan bahwa pengujian hipotesis pada literasi keuangan terhadap keputusan investasi menghasilkan nilai koefisien korelasi sebesar 0,617 dengan nilai $\mathrm{p}$ value sebesar 0,000 ( $\mathrm{p}$ value $<0,050)$. Hal tersebut menunjukkan bahwa literasi keuangan berpengaruh signifikan terhadap keputusan investasi. Dengan demikian H1 diterima.

Hal ini memiliki makna bahwa tingkat literasi keuangan adalah hal yang penting karena memungkinkan individu untuk melakukan sebuah investasi. Pemahaman individu tentang dasar mengenai keuangan pribadi, pengetahuan manajemen uang, pengetahuan manajemen kredit dan hutang, pengetahuan tabungan dan investasi dan pengetahuan manajemen risiko mengetahui kerja suku bunga, memiliki pengaruh terhadap individu untuk melakukan investasi. Salah satu alasan ketika individu tidak memiliki niat 
untuk melakukan sebuah investasi adalah rendahnya tingkat literasi keuangan yang dimiliki.

Hal ini mendukung hasil penelitian yang dilakukan oleh (Welly:2016) menyatakan bahwa literasi keuangan merupakan kemampuan seseorang dalam membuat keputusan yang efektif berhubungan dengan keuangan. Literasi keuangan membantu individu terhindar dari masalah keuangan terutama yang terjadi akibat kesalahan pengelolaan keuangan. Literasi keuangan bagi individu bukan sekedar sebagai ilmu pengetahuan ataupun teori saja, tetapi diharapkan dapat membuat individu lebih bijaksana dan pandai dalam mengelola aset yang dimilikinya sehingga dapat memberikan timbal - balik yang bermanfaat dalam menyokong keuangan individu baik dalam jangka pendek maupun jangka panjang.

(Hisashi dan Ratna, 2016) melakukan pengujian pada nasabah salah satu asuransi yang berada di Palembang menemukan bahwa, pengetahuan umum keuangan pribadi berpengaruh terhadap keputusan investasi seseorang. Sejalan dengan Hisashi dan Ratna (Sandy, 2016) melakukan pengujian pada masyarakat Malang Raya menemukan bahwa pengetahuan umum keuangan pribadi berpengaruh terhadap keputusan investasi. Kemudian Robb dan Woodyard (2011) secara teoritis literasi keuangan adalah bagian dari pengetahuan keuangan mengenai bagaimana pasar keuangan beroperasi harus menghasilkan individu yang membuat keputusan lebih efektif. Jagongo dan Mustwenje, (2014) menemukan bahwa sebagian besar responden tidak memahami konsep keuangan dasar, 
terutama yang berkaitan dengan saham, obligasi, reksadana dan konsep keuangan majemuk. Sehingga orang sering gagal dalam menyimpulkan serta mengambil keputusan.

Berdasarkan Tabel 5. dapat dijelaskan bahwa literasi keuangan berpengaruh signifikan terhadap perilaku keputusan investasi dengan koefisien sebesar 0,617 dan signifikan pada 0,05 ( $\mathrm{p}$ value $<0,05$ ). Pendapatan berpengaruh signifikan terhadap perilaku keputusan investasi dengan koefisien sebesar 0,310 dan signifikan pada 0,05 ( $\mathrm{p}$ value $<0,05$ ). Masa bekerja berpengaruh tidak signifikan terhadap perilaku keputusan investasi dengan koefisiean 0,006 pada signifikan 0,05 ( $\mathrm{p}$ value $>0,05)$.

Hasil estimasi model struktural seperti yang disajikan pada Tabel 5. menunjukkan bahwa pengujian hipotesis pada pendapatan terhadap perilaku keputusan investasi menghasilkan nilai koefisien sebesar 0,310 dengan $\mathrm{p}$ value sebesa 0,040 ( $\mathrm{p}$ value $<0,05$ ). Hal tersebut menunjukkan bahwa pendapatan berpengaruh signifikan terhadap perilaku keputusan investasi. Dengan demikian $\mathrm{H} 1$ diterima. Hal ini memiliki makna bahwa semakin baik pendapatan maka semakin tinggi pendapatan maka semakin baik dan bertanggungjawab perilaku keuangannya.

John et al, (2009) menyatakan bahwa terdapat hubungan yang positif antara pendapatan (income) dengan perilaku manajemen keuangan yang bertanggungjawab. Artinya semakin tinggi pendapatan maka semakin baik dan bertanggungjawab perilaku keuangannya. Hasil penelitian ini didukung oleh teori perpsektif perilaku keuangan dalam pengambil 
keputusan keuangan yang adaptif berarti bahwa sifat keputusan dan lingkungan di mana itu membuat pengaruh jenis proses yang digunakan. Semakin baik keadaan sosiodemografi seseorang akan berpengaruh terhadap jenis proses pengambilan keputusan investasi yang digunakan kearah yang baik. V. Sudheer (2015) menemukan hasil bahwa pendapatan berpengaruh signifikan terhadap kebutuhan serta keputusan investasi.

Hasil estimasi model struktural seperti yang disajikan pada Tabel 5. menunjukkan bahwa pengujian hipotesis pada masa bekerja terhadap perilaku keputusan investasi menghasilkan bila koefisien sebesar 0,006 dengan $\mathrm{p}$ value sebesar 0,950 ( $\mathrm{p}$ value $>0,05$ ). Hal ini menunjukkan masa kerja tidak berpengaruh signifikan terhadap keputusan investasi. Dengan demikian H1 ditolak.

Hal ini memiliki arti bahwa tidak adanya pengaruh masa bekerja seseorang dengan pengambilan keputusannya untuk melakukan sebuah investasi. Hasil penelitian ini tidak sejalan dengan hasil penelitian yang dilakukan tahun (2008) mengatakan bahwa seseorang yang tidak bekerja, memiliki tingkat financial literacy lebih rendah karena tidak pernah terlibat dengan isu - isu mengenai finansial. Hal senada juga diutarakan oleh Calamato (2010), bahwa kondisi kerja dapat mempengaruhi kinerja seseorang, sehingga dapat meningkatkan pendapatan dan mengelola gajinya dengan baik untuk kepentingannya, begitu juga dengan Krishna, Rofaida \& Sari (2010) yang menemukan bahwa masa bekerja seseorang berpengaruh secara positif dan signifikan terhadap perilaku keuangan 
Hal ini dikarenakan pada industri perbankan semua karyawan baik yang baru memasuki dunia kerja ataupun yang sudah lama bekerja sama sama mendapatkan pelatihan - pelatihan serta memperoleh informasi informasi mengenai perkembangan keuangan serta kondisi keuangan yang terjadi pada saat ini. Dengan kata lain karyawan yang baru pun memiliki pemahaman yang hampir sama dengan pemahaman karyawan yang telah lama bekerja. Sehingga masa kerja tidak berpengaruh signifikan terhadap perilaku keputusan investasi.

Hasil penelitian ini telah menunjukkan bagaimana pengaruh literasi keuangan, pendapatan dan masa bekerja terhadap perilaku keputusan investasi. Berdasarkan temuan tersebut, maka hasil penelitian ini mampu memperkaya konsep literasi keuangan yang dikemukakan oleh beberapa ahli terdahulu serta mendukung studi-studi empiris terkait pengetahuan manajemen keuangan yang menentukan perilaku keputusan investasi pada individu.

Berdasarkan hasil penelitian tersebut ada implikasi praktis yang dihasilkan. Berdasarkan analisis PLS yang menunjukkan bahwa literasi keuangan memiliki pengaruh paling besar dalam menentukan perilaku keputusan investasi individu dibandingkan dengan variabel pendapatan dan masa bekerja. Hal ini menjelaskan bahwa pengetahuan seseorang tentang mengelola keuangan pribadinya menjadi faktor utama dalam menentukan keputusan sebuah investasi. Informasi dan sosialisasi merupakan sumber dari pengetahuan pengelolaan keuangan. Pentingnya 
hal ini merupakan tugas yang besar bagi lembaga keuangan kepada masyarakat terlebih masyarakat yang telah memiliki pendapatan tetap berupa gaji per bulannya.

Literasi keuangan yang tinggi bermanfaat agar terhindar dari kesulitan finansial contohnya adalah melakukan perencanaan keuangan. Seseorang yang memiliki perencanaan keuangan adalah suatu hal yang penting. Dana yang disisihkan dapat digunakan sebagai dana cadangan yang sewaktu-waktu dapat digunakan dalam kondisi darurat atau untuk berinvestasi. Pengetahuan tentang pengelolaan keuangan pribadi penting dilakukan ketika usia produktif agar nantinya dapat selalu memenuhi kebutuhan akan hidup.

Penelitian ini hanya menggunakan responden karyawan yang bekerja di Bank saja, sehingga penting untuk penelitian dimasa mendatang melengkapi dan memperkaya studi empiris terkait topik dengan menggunakan responden lain, disarankan seperti responden usia remaja karena literasi keuangan dan perilaku investasi penting dimiliki pada usia sedini mungkin. Pada penelitian selanjutnya diharapkan juga peneliti mampu memberikan informasi mengenai perbedaan perilaku keputusan investasi individu berdasarkan jenis pekerjaannya seperti PNS atau Swasta.

Variabel pada penelitian ini hanya menggunakan literasi keuangan dalam bidang ilmu manajemen keuangan dalam konteks perilaku. Masih banyak variabel-variabel lain yang perlu diteliti kembali dimasa datang 
untuk menambahkan empiris dan teori mengenai perilaku terkait ilmu manajemen keuangan. Variabel yang disarankan untuk penelitian di masa depan adalah kepuasan keuangan (financial satisfaction) dan perilaku keuangan (financial behavior) dalam perilaku keputusan investasi individu.

\section{SIMPULAN DAN SARAN}

Berdasarkan hasil pembahasan penelitian yang telah dilakukan, maka dapat disimpulkan bahwa Literasi keuangan berpengaruh positif signifikan terhadap perilaku keputusan investasi individu. Artinya, semakin tinggi tingkat literasi keuangan, maka semakin baik perilaku keputusan investasi individu. Pendapatan berpengaruh positif signifikan terhadap perilaku keputusan investasi individu. Artinya, adanya semakin tinggi pendapatan seseorang, maka semakin baik perilaku keputusan investasi individu.

Masa bekerja tidak berpengaruh signifikan terhadap perilaku keputusan investasi individu. Artinya, tidak adanya perbedaan signifikan antara karyawan yang baru bekerja dengan karyawan yang telah lama bekerja dalam perilaku keputusan investasi individu. Hal ini dikarenakan adanya sosialisasi yang rutin mengenai literasi keuangan serta perkembangan mengenai isu - isu terkini mengenai keuangan seperti perkembangan suku bunga Bank Indonesia.

Saran yang dapat diberikan berdasarkan kesimpulan yang didapat adalah Bagi karyawan serta masyarakat menyadari bahwa pentingnya literasi keuangan dalam pengelolaan dana, karena faktor literasi keuangan merupakan faktor utama 
di dalam melakukan sebuah investasi dimana investasi tersebut akan bermanfaat ketika masa yang akan datang.

Bagi karyawan yang memiliki tingkat pendapatan yang tinggi, dihimbau agar menggali informasi mengenai perkembangan seperti suku bunga, kurs mata uang, permasalahan sosial, isu politik serta perkembangan informasi mengenai investasi agar yang dimiliki tidak dihabiskan untuk konsumsi ataupun hal - hal yang dapat merugikan.

Penelitian dimasa mendatang diharapkan mampu melengkapi serta memperkaya studi empiris terkait topik dengan menggunakan responden lainnya, disarankan seperti responden dinas atau lembaga keuangan lainnya, karena pada dasarnya dinas serta lembaga keuangan selayaknya memiliki literasi keuangan serta perilaku keputusan investasi yang tinggi.

Penelitian dimasa mendatang diharapkan mampu menambahkan variabel variabel lain yang tidak terdapat dalam penelitian ini seperti jenis kelamin, usia, status kepemilikan tempat tinggal, menjadikan variabel literasi keuangan sebagai variabel moderasi.

Penelitian dimasa datang diharapkan mampu mengembangkan empiris dan teori mengenai perilaku terkait dengan ilmu manajemen keuangan.

\section{REFERENSI}

Awais, M., Laber,M.F., Rasheed, N., Khursheed, A. 2016. Impact of Financial Literacy and Investment Experience on Risk Tolerance and Investment Decision : Empirical Evidence from Pakistan. International Journal of Economics and Financial Issues. Vol.6, 73-79

Calamato, M. P. 2010. Learning financial literacy in the family. San Jose State University. Master's Theses.3849 
Chen, H., \& Volpe, R. P. 2002. Gender differences in personal financial literacy among college students. Financial Services Review, 11, 289-307.

Faoziah I, Sarojani DK, Norfiza A 2013. Relationship between financial literacy and financial distress among youths in Malaysia -An empirical study. Geografia - Malaysian Journal of Society and Space

Hisashi, T. \& Ratna, J. 2016. Analisis Pengaruh Literasi Keuangan terhadap Keputusan Investasi, Studi Kasus Nasabah Asuransi Generali Indonesia Cabang Palembang.

Janor, H., Yakob, R., Noor, A.H., Zanariah, Che, A.C.W 2016. Financial Literaci and Investment Decisions in Malaysia and United Kingdom: A Comparative analysis.

John, G. E., Park, J.-Y., \& Joo, S.-H. 2009. Explaining Financial Management Behavior for Koreans Living in the United States. The Journal of Consumer Affairs , 80.

Klapper L, Georgios AP 2011. Financial Literacy and Retirement Planning in View of a Growing Youth Demographic: The Russian Case.CeRP Working Paper No.114/11

Kompas.com Hari "Gini" tak Seperempat Jumlah Orang Indonesia Punya Rekening.

Kompas.com Dukung Literasi Keuangan, BCA dan OJK Lanjutkan Pengoperasian SiMOLEK. Terbit 15 Mei 2016.

Kompas.com OJK Akan Buat Aturan Baru tentang Literasi Keuangan. Terbit 23 Juni 2016.

Kompas.com OJK dan Pemprov Jateng Kerja Sama Percepat Akses Literasi Keuangan Masyarakat. Terbit 16 Juli 2016.

Kompas.com Indeks Literasi Keuangan Indonesia 2016 Naik Jadi 29,66 Persen.Terbit 24 Januari 2017.

Kompas.com Perluas Literas Keuangan, OJK Jalin Kerjasama dengan Muhammadiyah. Terbit 18 April 2017.

Kompas.com Apa Fokus OJK untuk Edukasi, Literasi Keuangan dan Perlindungan Konsumen? Terbit 04 April 2017 
Lusardi, A., Mitchell, O. S., \& Curto, V. 2010. Financial literacy among the young. The Journal of Consumer Affairs, 44(2), 358-380. http://dx.doi.org/10.1111/j.1745-6606.2010.01173.x

Monticone, C 2010. How Much Does Wealth Matter In The Acquisition of Financial Literacy?. The Journal of Consumer Affairs, 44 (2)

Monticone, Chiara 2010. Financial Literacy and Financial Advice Theory and Empirical Evidence.

Nababan, Darman. 2012. Analisis Personal Financial Literacy dan Financial Berhavior Mahasiswa Strata I Fakultas Ekonomi Universitas Sumatera Utara. Universitas Sumatera Utara, Medan.

Narindra Mandala, Wiagustini .2017. Pengaruh Variabel Sosial Ekonomi, Demografi, dan IPK terhadap Financial Literacy.(Studi Kasus terhadap Mahasiswa Magister Manajemen di Universitas Udayana). E Jurnal Ekonomi dan Bisnis Universitas Udayana $6.12(2017) .4225-4254$

Robb, C. A., \& Woodyard, A. S. 2011. finanacial knowledge and best practice behaviour. Journal of financial Counseling and planning Volume 22 Issue 1.

Sekaran, U. \& Bougie, R. 2009. Methods for Business-Method for Business-A Skill-Building Approach.5th Edition.United Kingdom:John Wiley \& Sons Ltd.

Sugiyono 2013. Metode Penelitian Kuantitatif dan R \& D. Alfabeta Bandung.

V.Sudherr. 2015 Impact of Socioeconomic Factors on Investors' Investment Culture. The International Journal of Business and Management Vol 3 Issue 7 Juli 2015.

Warsono, 2010. Prinsip-prinsip dan Praktik Keuangan Pribadi, Journal of Science. Volume 13 Nomor 2 Juli - Desember 2010, Hal 15 28.

Welly, Kardinal, Ratna, J. 2016. Analisis Pengaruh Literasi Keuangan terhadap Keputusan Investasi di STIE Multi Data Palembang.

Yoong FJ, See BL, Baronovich DL 2012. Financial Literacy key to retirement planning in Malaysia. Journal of Management and Sustainability 